Rizqy Aji Nugroho

2301912776

\title{
Employee Agility
}

Employe Agility Ini adalah sifat yang ditunjukkan melalui keterampilan kolaborasi yang hebat, sikap cepat gagal, kemauan untuk menerima perubahan, ketahanan dalam menghadapi kemunduran, dan keinginan untuk menjadi pembelajar yang konstan. Karyawan yang gesit mahir bekerja dalam tim lintas fungsi. Kelincahan di tempat kerja menentukan kemampuan organisasi untuk bekerja dengan cepat, lancar, dan kohesif untuk menghasilkan peningkatan produktivitas dan tingkat keterlibatan. Sifat kelincahan juga membantu organisasi beradaptasi dan berbaur dengan baik dengan perkembangan dan perubahan yang terjadi seiring waktu di seluruh pasar.

3 Steps on the Path to Agility

- Empower employees and simplify processes to work faster.

- Create an environment where employees can try out new ideas.

- Increase capacity through cross-team coordination.

Karyawan merupakan aset penting bagi organisasi untuk mencapai tujuan dan sasaran organisasi. Kelincahan dan pengalaman digital organisasi sumber daya manusia membantu menciptakan kemampuan karyawan untuk melakukan dan mencapai tujuannya. Untuk memperkuat pengalaman digital karyawan melalui pemikiran desain, analisis yang stabil terhadap orang-orang di tempat kerja, dan transformasi. Dalam lingkungan yang tidak pasti dan dengan kemajuan teknologi, organisasi harus mengatasi hambatan kinerja untuk mempertahankan keunggulan kompetiti.

Beberapa faktor yang mempengaruhi organisasi untuk meningkatkan kelincahan organisasi, seperti persaingan produk, kemajuan teknologi, dan keunggulan kompetitif. Kemajuan teknologi memaksa organisasi untuk mengadopsi praktik kelincahan perusahaan untuk meningkatkan efektivitas perusahaan. Teknologi informasi diperlukan bagi organisasi untuk mengadopsi tren teknologi terkini. Kemampuan organisasi mendukung kelincahan organisasi untuk berkembang dalam situasi yang tidak pasti dan perubahan yang dinamis. Sumber daya organisasi, terutama karyawan, harus memiliki keahlian digital di tempat kerja untuk membantu merespons dengan cepat perubahan teknologi dan ketidakpastian lingkungan untuk keberlanjutan dan kinerja. Dalam lingkungan yang tidak pasti dan dengan kemajuan teknologi, organisasi harus mengatasi hambatan kinerja untuk mempertahankan keunggulan kompetitif. Hambatan kinerja dan gangguan digital terjadi di seluruh teknologi, masyarakat, dan model bisnis yang berdampak pada datangnya pekerjaan, yang membutuhkan kelincahan dan keahlian digital dari karyawan. Dalam penelitian ini, ada tiga hal baru. Pertama, penelitian tentang digital employee experience merupakan sesuatu yang baru dan baru berkembang dalam beberapa tahun terakhir. Yang kedua dari segi objek penelitian adalah perusahaan dry port. Ketiga, mempelajari dampak pengalaman karyawan digital dan kelincahan karyawan terhadap efektivitas perusahaan dry port.

Dry Port Firm Effectiveness 
Efektivitas Perusahaan adalah konsep sentral dari manajemen organisasi. Efektivitas organisasi adalah kemampuan organisasi untuk bertahan dan mencapai tujuan serta mencukupi secara finansial. Istilah efektivitas organisasi dan kinerja organisasi telah digunakan secara bergantian untuk hasil perusahaan. Definisi efektivitas perusahaan dalam penelitian ini adalah kemampuan organisasi untuk mencapai tujuannya melalui penggunaan sumber daya secara efektif sambil beradaptasi dengan lingkungan eksternal.

Literatur sebelumnya tentang ukuran efektivitas pelabuhan kering berfokus pada dimensi terbatas untuk mengukur kinerja pelabuhan atau area pelabuhan tertentu. Pemilihan indikator didasarkan pada tinjauan literatur yang berbeda dan potensial dan beberapa studi dengan penelitian pelabuhan dan terminal yang mendukung studi ini dengan pengetahuan empirisnya. Pemilihan indikator didasarkan pada tinjauan literatur yang berbeda dan potensial dan beberapa studi dengan penelitian pelabuhan dan terminal.

Relationship Between Digital Employee Experience and Dry Port Firm's Effectiveness

Pengalaman kerja karyawan melibatkan beberapa faktor, antara lain menemukan makna pekerjaan, berinteraksi, dan menanggapi praktik internal di tempat kerja. Pengalaman kerja karyawan akan menciptakan keterikatan karyawan yang lebih besar, dan karyawan sangat berkomitmen untuk membangun pengalaman yang lebih baik bagi pelanggan dan karyawan lainnya. Ciptakan pengalaman kerja karyawan yang melibatkan komponen manusia dan teknologi digital. Teknologi adalah faktor penting untuk transformasi digital dari pengalaman pengguna. Pengalaman karyawan digital mengintegrasikan teknologi ke dalam titik kontak karyawan yang kritis dan merancang seluruh siklus hidup karyawan dari 'perekrutan hingga pembelajaran' dengan gerakan digital.

Pengalaman digital karyawan muncul dalam digitalisasi di perusahaan dan memberikan pengetahuan baru untuk mengatasi masalah dan kebutuhan untuk mencapai efektivitas perusahaan dan mengintegrasikan dan mengkoordinasikan berbagai kegiatan perusahaan. Hal ini kemudian memungkinkan untuk memenuhi kebutuhan staf untuk dianggap sebagai peluang bisnis yang strategis. Dalam bisnis dry port, pengalaman digital karyawan menempatkan orang-orang di pusat operasi bisnis, menyadari bahwa sistem dan proses harus produktif dan menyenangkan. Dan banyak yang menetapkan peran baru untuk memberikan pengalaman karyawan digital. Dibutuhkan berbagai format, termasuk manajer saluran digital internal, manajer pengalaman digital, dan tim pengalaman karyawan

Munculnya poin-poin baru, seperti transformasi digital di dunia bisnis, khususnya perusahaan dry port, belakangan ini. Beberapa spesialis setuju bahwa peningkatan profitabilitas dan kelangsungan hidup organisasi pelabuhan kering bergantung pada partisipasi dalam perjalanan transformasi digital tahun depat. Pemimpin yang berorientasi digital harus terus menantang organisasi mereka dan memberikan pengalaman digital kepada karyawan untuk memastikan bahwa perubahan menciptakan keunggulan kompetitif dan efektivitas bagi organisasi.

Relationship Between Employee Agility and Dry port Firm Effectiveness 
Kelincahan adalah kemampuan untuk menjadi kreatif dan mengatasi perubahan tak terduga untuk mencapai tujuan dalam lingkungan bisnis yang dinamis dan menyeimbangkan fleksibilitas dan stabilitas. Agility melihat keterbatasan perubahan dalam keadaan minimal dan merespon setiap perubahan yang mungkin dan tidak terduga, sementara fleksibilitas merespon perubahan yang direncanakan. akuntabilitas dan kelincahan dalam produksi dapat dicapai melalui teknologi canggih di masa lalu. Sementara integrasi komputer dapat memberikan keunggulan kompetitif, mencapai fleksibilitas dalam produksi dan layanan memerlukan pengembangan dan pemeliharaan elemen teknologi tinggi dan sumber daya manusia untuk menghadapi situasi yang tidak terduga. Oleh karena itu, kita harus mengenali peran tenaga manusia dalam mempromosikan kelincahan. Kelincahan sumber daya manusia merupakan salah satu dimensi kelincahan organisasi dalam organisasi untuk mencapai efektivitas perusahaan.

\section{Kesimpulan}

Dengan pengalaman digital karyawan, seperti asisten virtual SDM, mereka dapat membantu dengan kebijakan perusahaan yang diperlukan untuk karyawan, seperti tunjangan, rencana liburan, dan magang di tempat kerja. Mereka dapat menghasilkan surat kerja standar berdasarkan kebutuhan karyawan. Karyawan memiliki hidangan utama untuk asisten ini, yang mendukung perusahaan meningkatkan efektivitas dengan menghemat banyak waktu. Pengalaman digital yang memerlukan Keterlibatan dan kolaborasi dapat memberikan pemahaman yang lebih mendalam tentang pemahaman dan asumsi pekerja bagi perusahaan dan direktur, memungkinkan mereka untuk bereaksi sesuai jadwal jika ada adalah masalah yang harus cenderung. Pada intinya, pengalaman karyawan digital mengharuskan perusahaan, terutama Divisi Human Capital, memiliki kemampuan manajemen data yang benar untuk menganalisis dan berkontribusi dalam pengambilan keputusan yang sukses. Seiring dengan banyak sistem informasi sumber daya manusia, perusahaan menawarkan beberapa kali, di mana saja fasilitas bantuan dengan aplikasi, telepon, dan biaya lain yang dikeluarkan untuk kebutuhan karyawan.

Karyawan yang gesit dapat menjadi jawaban yang tepat untuk mencapai efektivitas perusahaan, dan mereka mencoba mengintegrasikan pola pikir dan perilaku yang lebih gesit ke dalam bisnis sehari-hari mereka. Khususnya dalam organisasi pelabuhan kering, langkah menuju kelincahan ini telah terbukti menjadi usaha yang menantang. Untuk memasukkan kelincahan ke dalam budaya mereka, organisasi harus menggunakan strategi yang berbeda untuk mencapai Efektivitas yang Kuat. Sebuah perusahaan dengan karyawan kelincahan yang sukses membutuhkan aspirasi, komitmen, alokasi sumber daya, pengukuran kemajuan, dan penghargaan. Kombinasi dari semua faktor tersebut dapat meningkatkan kelincahan dalam suatu perusahaan. 


\section{Referensi:}

D. H. Syahchari, Lasmy, M. G. Herlina, H. Saroso, D. Sudrajat and H. K. W. Jordaan, "The Influence of Digital Employee Experience and Employee Agility: Do They Boost Firm's Effectiveness?," 2021 International Conference on Information Management and Technology (ICIMTech), 2021, pp. 67-71, doi: 10.1109/ICIMTech53080.2021.9534976.

Lasmy, L., Sudrajat, D., Syahchari, D. H., Herlina, M. G., Saroso, H., \& Moeke, D. (2021). Role of employee agility on indonesian dry port firm's effectiveness with agile is infrastructure as moderation. Paper presented at the Proceedings of 2021 International Conference on Information Management Technology, 2021, 137-142. doi:10.1109/ICIMTech53080.2021.9534925 Retrieved from www.scopus.com 